\title{
PENGEMBANGAN MODEL MODIFIKASI PERILAKU TERINTEGRASI PROGRAM PEMBELAJARAN UNTUK ANAK DENGAN MASALAH PERILAKU
}

\author{
Edi Purwanta, Pujaningsih, Aini Mahabbati, dan Heri Purwanta \\ Fakultas Ilmu Pendidikan Universitas Negeri Yogyakarta \\ email: edi_plb@yahoo.co.id
}

\begin{abstract}
Abstrak: Penelitian ini bertujuan untuk mengetahui permasalahan perilaku yang banyak ditemukan di SLB E, mengetahui kebutuhan guru terkait penanganan permasalahan perilaku, dan mengembangkan model modifikasi perilaku terintegrasi pembelajaran untuk anak gangguan perilaku. Penelitian menggunakan pendekatan research and development dengan subjek penelitian siswa dan guru SLB-E Bina Putera Surakarta. Hasil penelitian menunjukkan seperti berikut. (1) Perilaku bermasalah yang banyak ditemukan adalah bermasalah internal dan eksternal dengan latar belakang menghindar (escape) pembelajaran. (2) Kebutuhan guru dalam penanganan permasalahan perilaku berupa pengetahuan dan keterampilan asesmen perilaku dalam pembelajaran, merancang Program Pembelajaran Individual (PPI) sesuai dengan karakteristik individual siswa dengan memasukkan unsur pengelolaan perilaku bermasalah dalam skenario pembelajaran, dan teknik-teknik modifikasi perilaku yang integratif dengan pembelajaran. (3) Model modifikasi perilaku terintegrasi pembelajaran dimulai menemukan latar belakang perilaku bermasalah, modifikasi perilaku diawali dengan asesmen mendalam mengenai antecedent dan consequence dari perilaku, dan menerapkan perbaikan perilaku sesuai jenis dan latar belakang perilaku bermasalah.
\end{abstract}

Kata Kunci : masalah perilaku, model modifikasi terintegrasi

\section{DEVELOPMENT OF A BEHAVIOR MODIFICATION MODEL INTEGRATED IN THE TEACHING PROGRAM FOR CHILDREN WITHMISBEHAVED}

\begin{abstract}
This study was aimed to reveal the behavioral problems found in SLB E, reveal teachers' needs in relation to how to deal with the misbehavior, to develop a behavior modification model integrated in teaching for children with misbehavior. This study used the research and development approach. The subjects were SLB E Bina Putera students and teachers. The findings showed: (1) the misbehavior found was internal misbehavior and external misbehavior by escaping from the teaching activity as the background of the behavior; (2) the teachers' needs in dealing with misbehavior was in the form of knowledge and skills in assessing the behavior in the teaching activity, designing the Individualized Educational Program (IEP) in accordance with the characteristics of the students by integrating the management components of misbehavior in the teaching scenario, and techniques of behavior modification integrated in the teaching activity; (3) a behavior modification model integrated in the teaching activity by finding out the background of the misbehavior, behavior modification initiated by in-depth assessment about the antecedent and consequence of the behavior, and the application of the behavior improvement in accordance with the type and background of the misbehavior.
\end{abstract}

Keywords: misbehavior, behavior modification model

\section{PENDAHULUAN}

Gangguan perilaku adalah gangguan penyesuaian diri terhadap lingkungan sosial yang disebabkan lemahnya kontrol diri dan hal itu merupakan kasus yang paling banyak terjadi pada anak-anak (Muhammad Dwi, 2010:7).
Mereka saat ini dilayani secara khusus di SLB E dan dijumpai di sekolah-sekolah reguler di berbagai jenjang. Di negara maju ditemukan $19,6 \%$ anak dengan permasalahan perilaku berada di sekolah reguler (Smith, 1998:102). Hal tersebut disebabkan sebagian besar permasalah- 
an perilaku merupakan dampak penyerta kebutuhan khusus pada anak berkebutuhan khusus. Misalnya, anak dengan masalah akademik dapat terlihat mengalami masalah perilaku di kelas karena ia tidak dapat berpartisipasi di kelas yang disebabkan pembelajaran tidak sesuai level kemampuan anak.

Permasalahan perilaku dan emosi pada anak tersebut apabila tidak ditangani dapat berkembang pada permasalahan yang lebih kompleks. McCabe mengemukakan bahwa tidak semua anak dengan perilaku dan emosi akan menjadi orang dewasa dengan anti sosial, namun sebagian besar di antara mereka setelah dewasa cenderung terlibat tindakan kriminal dan bermasalah dengan obat-obatan (Muhammad Dwi, 2010:7). Selain itu, Carr mengemukakan bahwa anak cenderung memiliki masalah psikologis, sulit menyesuaikan diri dengan pendidikan dan pekerjaan, memiliki perkawinan yang tidak stabil, resisten terhadap upaya penyembuhan, serta cenderung bersikap keras dalam mengasuh anak-anaknya yang kemudian juga akan memicu permasalahan serupa pada generasi berikutnya (Muhammad Dwi, 2010:7). Untuk itu, diperlukan upaya perbaikan terhadap perilaku yang bermasalah. Berbagai upaya telah banyak dilakukan, namun upaya yang edukatif melalui modifikasi perilaku.

Modifikasi perilaku merupakan penerapan teori belajar operant conditioning untuk mengubah perilaku. Operan conditioning ditemukan oleh B.F Skinner mengacu pada hubungan antara lingkungan yang menghasilkan perubahan perilaku yang spesifik. Asumsi yang berkaitan dengan modifikasi perilaku antara lain seperti berikut. (1) Perilaku merupakan sesuatu yang dipelajari. (2) Perilaku tidak permanen namun dapat dilatih, diajarkan dan dirubah atau dimodifikasi. (3) Sebagian besar perilaku merupakan hasil dari rangsangan tertentu, misalnya saat ada nyamuk menggigit maka orang akan tergerak untuk memukulnya. Perilaku tidak terjadi secara acak, tetapi karena stimulus. (4) Program pengelolaan perilaku seharusnya spesifik untuk setiap perilaku yang akan dimodifikasi. (5) Program pengelolaan perilaku harus difokuskan pada lingkungan anak, bukan pada hanya anak.
Tahap awal dalam modifikasi perilaku adalah memahami perilaku bermasalah. Perilaku bermasalah dapat dipahami dari motif atau latar belakang perilaku bermasalah yang dilakukan. Empat kemungkinan anak melakukan perilaku yang tidak diinginkan (Smith, 2010:13; Joosten \& Bundy, 2008: 1342) adalah sebagai berikut. (1) Mencari perhatian, contoh anak yang suka berjalan-jalan di kelas untuk mendapat perhatian guru. (2) Ketidakmampuan untuk memperoleh yang diinginkan, contoh: seorang anak yang menunjuk untuk membeli sesuatu tapi ibu bilang 'tidak' dan anak mulai menangis. (3) Menghindar atau lari dari suatu kegiatan/orang tertentu, contoh: anak yang tiba-tiba sakit perut saat belajar membaca. (4) Kebutuhan akan rangsangan dari dalam, contoh masturbasi. Perilaku ini dapat muncul karena tidak ada perilaku yang menyenangkan dari luar.

Memahami perilaku bermasalah juga dilakukan dengan mengidentikasi bentuk perilaku tersebut. Terdapat dua bentuk permasalahan perilaku yang dapat dikelola, yaitu perilaku defisit (lemah) dan perilaku maladaptif (excessive behavior). Perilaku defisit ditunjukkan dalam dua situasi, yaitu sebagai berikut.

- Gagal dalam menunjukkan suatu perilaku yang memperhatikan kesesuaian pada usia, waktu dan tempat.

- Untuk rangsangan yang diberikan, anak gagal merespon kejadian yang diukur dalam hal-hal seperti berikut.

- Frekuensi yang diinginkan.

- Intensitas yang mencukupi, banyak dikaitkan dengan perilaku sosial dan komunikasi. Contoh: membaca paragraf.: anak yang membaca nyaring tapi dengan suara lemah.

- Cara yang tidak wajar dikaitkan dengan norma sosial yang sesuai. Contoh: saat diberi salam, anak menjawab tanpa melihat pemberi salam.

- Di bawah kondisi sosial yang dapat diterima (Alberto \& Troutman, 1995:245).

Perilaku berlebihan merupakan perilaku yang muncul pada waktu dan tempat yang tidak tepat dalam hal: (1) frekuensi (berapa banyak?) perilaku terjadi, misalnya: berapa kali anak 
hand flapping selama 15 menit; (2) durasi (berapa lama?) perilaku berlangsung, contoh: 1-3 menit; (3) intensitas (kedalaman/keseriusan) perilaku yang terjadi.

Anak dengan permasalahan emosi dan perilaku sering mengalami perlakuan yang tidak sesuai dari lingkungannya (Wiguna, dkk. 2010: 270). Hal tersebut disebabkan guru kesulitan mengajar mereka, melihat sebagai anak bodoh sehingga jarang memberikan masukan positif. Di sisi lain, teman sebaya menghindari mereka sehingga interaksi sosial mereka menjadi terbatas. Kritik negatif juga sering ditujukan oleh orang tua dan menyebabkan mereka semakin tersudut oleh permasalahan perilaku dan emosi tersebut.

Permasalahan dalam menangani anak dengan masalah perilaku tidak hanya dijumpai di sekolah reguler, namun juga sekolah khusus. Hal tersebut dapat diketahui berdasarkan kunjungan lapangan mahasiswa PLB di SLB Bina Putra Solo. Sekolah tersebut memiliki murid sebanyak 80 orang dengan tenaga pengajar berjumlah 18 orang. Permasalahan mendasar yang menjadi keluhan bagi guru adalah pengelolaan perilaku anak yang masih banyak menggunakan strategi punishment ternyata tidak kunjung menunjukkan hasil yang diharapkan. Penguasaan guru yang minim mengenai strategi pengelolaan perilaku merupakan salah satu sebab dari munculnya situasi tersebut.

Sebagai sekolah khusus yang menangani anak dengan permasalahan perilaku dan emosi, maka program bina perilaku dan sosial banyak didasarkan pada penguasaan strategi pengelolaan perilaku. Bila keterampilan tersebut tidak dikuasai oleh guru, kebutuhan anak dengan masalah perilaku tidak akan terpenuhi. Hal tersebut dapat mengarah pada akumulasi permasalahan yang semakin kompleks.

Berdasarkan persoalan di atas, penting bagi guru anak dengan masalah perilaku untuk menguasai metode dan teknik-teknik modifikasi perilaku. Modifikasi perilaku merupakan cara yang tersistem dan prosedural untuk mengelola perilaku bermasalah. Namun, strategi modifikasi perilaku yang banyak dipaparkan dalam pedoman maupun buku cetak masih sulit di- pahami oleh guru karena dilakukan secara klinis. Dalam konteks sekolah, strategi tersebut perlu diintegrasi dengan pembelajaran sehingga mudah dalam implementasi. Modifikasi perilaku yang diterapkan secara tepat dan terintegrasi dalam pembelajaran di kelas akan membantu guru untuk mengelola perilaku anak dan meningkatkan kualitas pembelajaran. Hasil penelitian Mahabbati (2012:xvii) menyatakan bahwa anak dengan gangguan perilaku (conduct disorders) mengalami peningkatan keterampilan sosial dalam konteks pembelajaran di sekolah rata-rata sebesar $15,19 \%$ setelah diterapkan Program Dukungan Perilaku Positif sebagai salah satu pendekatan modifikasi perilaku. Salah satu faktor yang berpengaruh pada peningkatan tersebut adalah keterlibatan aktif guru untuk menerapkan metode dan teknik modifikasi perilaku yang sesuai dengan karakter siswanya. Oleh karena itu, model modifikasi perilaku yang terintegrasi dalam pembelajaran perlu dikembangkan untuk membantu guru menangani anak dengan permasalahan perilaku. Model ini diharapkan akan dapat menjadi dasar pengembangan modul penanganan anak gangguan perilaku untuk guru di SLB maupun di sekolah inklusi.

\section{METODE}

Penelitian ini menggunakan penelitian dan pengembangan (Research and Development/ R \& D) yang didefinisikan oleh Gall, dkk. (2003: 570) sebagai "a process used to develop and validate educational product". Produk yang dihasilkan berupa model modifikasi perilaku terintegrasi program pembelajaran untuk anak dengan masalah perilaku di SLB E.

Penelitian ini diselesaikan dalam dua tahap penelitian yang masing-masing dalam diselesaikan dalam satu tahun. Pendekatan dan metode tiap tahunnya berbeda sesuai tujuan. Tahap pertama menggunakan metode deskriptif untuk mendapat data awal yang menjadi studi pendahuluan (pilot research) dan penelitian tindakan kelas pada tahap ujicoba awal. Tahap kedua menggunakan model workshop, uji lapangan diperluas, dan uji keterbacaan. Metode yang digunakan adalah evaluatif untuk meng- 
evaluasi hasil workshop, proses uji keterbacaan, dan uji coba pengembangan model. Alur desain penelitian pada tahap pertama ditunjukkan pada Gambar 1.

Subjek penelitian adalah guru dan murid di SLB E Bina Putra Solo. Sekolah tersebut menjadi sasaran penelitian ini berdasarkan hasil observasi sebelumnya yang dilakukan oleh tim peneliti dan menemukan bahwa kasus permasalahan perilaku di sekolah tersebut memerlukan penanganan segera serta motivasi dari pendidik yang tinggi untuk menangani kasus permasalahan perilaku dengan pendekatan modifikasi perilaku.

Setting dan waktu penelitian secara keseluruhan dilakukan dalam dua tahap, masingmasing tahapan dilakukan selama empat bulan. Lokasi penelitian ini adalah SLB E di Solo dan Yogyakarta. Pada tahap pertama lokasi penelitian mengambil di SLB E Bina Putra Solo.

Teknik pengumpulan data dilakukan berdasarkan tujuan penelitian (Arikunto, 2005: 39). Teknik pengumpulan data yang digunakan adalah observasi terstruktur, wawancara, angket, focus group discussion (FGD), dokumentasi, dan angket. Semua dilakukan untuk menjaring data berupa identifikasi permasalahan perilaku dan penanganan yang sudah dilakukan oleh guru-guru SLB E. Observasi terstruktur yang dipergunakan ditujukan untuk mengamati perilaku, antecedents, dan consequences menggunakan pedoman pengamatan yang sebelumnya telah disusun secara sistematis, berupa lembar observasi A-B-C Perilaku. Wawancara secara tidak terstruktur untuk mengungkap mengenai kasus permasalahan perilaku serta upaya yang sudah dilakukan. Angket juga diberikan untuk menjaring data terkait yang lebih jeli dan mungkin belum terekam. Dokumentasi yang ingin dikumpulkan adalah rekaman kasus permasalahan perilaku yang dimiliki oleh sekolah serta dokumen tertulis penanganan yang dilakukan oleh guru. Motivation Assessment Scale (MAS) dari Durrand dan Crimmins yang diisi guru untuk mengukur motivasi perilaku pada anak berkebutuhan khusus yang mengalami masalah perilaku (Smith, 2010:11), sebagai triangulasi terhadap observasi dan analisa A-B-C Perilaku. Sub-skala MAS mencakup empat motivasi perilaku bermasalah, yakni (1) attention, (2) tangible, (3) sensory, dan (4) escape dari perhatian, aktivitas, dan sensasi tidak diinginkan (Smith, 2010:12; Joosten \& Bundy, 2008:1341). Analisis dilakukan dengan menghitung rata-rata skor masing-masing subskala dengan rumus $\left(\left(\sum\right.\right.$ Xsub)/4), kemudian merangkingkan (Durrand \& Crimmins, 2000:1).

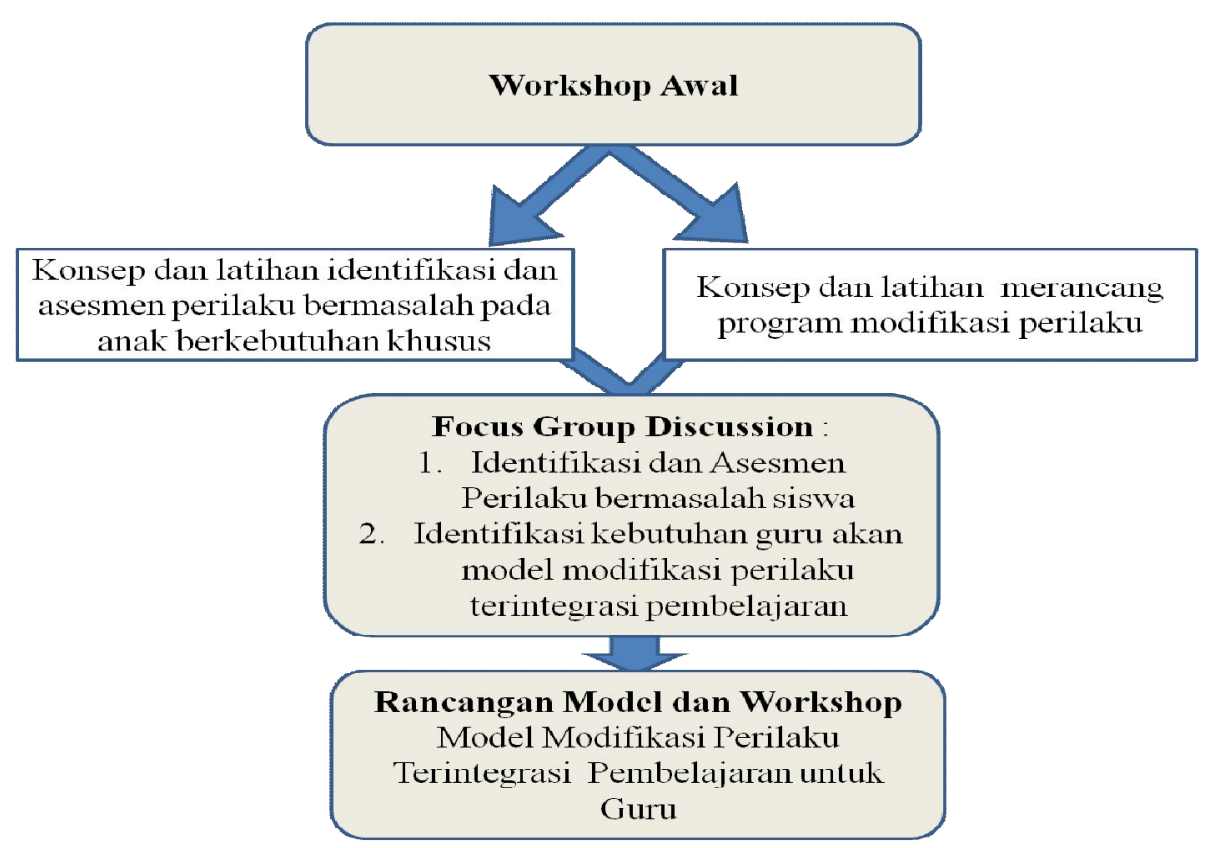

Gambar 1. Bagan Alir Penelitian 
Analisis data tahun pertama menggunakan deskriptif kualitatif dengan dukungan narasi maupun presentase untuk memaparkan halhal seperti berikut. (1) Permasalahan perilaku pada anak-anak (minimal 10 kasus) yang mencakup jenis gangguan perilaku, motif perilaku dan hasil dari intervensi permasalahan perilaku serta penanganan yang sudah dilakukan oleh guru beserta hasilnya. (2) Kebutuhan guru akan pengembangan model modifikasi perilaku terkait dengan instrumen, prosedur dan pelaporan yang integratif dengan pembelajaran.

\section{HASIL DAN PEMBAHASAN Lokasi Penelitian}

Lokasi penelitian ini adalah SLB E Bina Putera Surakarta yang merupakan sekolah khusus untuk ABK terutama yang mengalami gangguan perilaku. Menurut sejarahnya, sekolah berdiri dengan diawali berdirinya Yayasan Pembinaan Anak Nakal (YPAN) Bina Putera pada 26 Juni 1969. Beberapa bulan kemudian SLB E Bina Putera resmi berdiri dengan sasaran utama anak-anak nakal atau berperilaku menyimpang yang belum ditangani dengan pendekatan sekolah atau pendidikan alternatif.

Konsep pendidikan alternatif yang diterapkan di sekolah adalah pendidikan dan pembimbingan. Pelaksanaan pendidikan dipayungi oleh kebijakan dinas pendidikan dan berlangsung secara formal pada jam sekolah (pagi sampai siang). Muatan kurikulum sama dengan kurikulum SD, SMP, dan SMU umum namun dilaksanakan secara lebih fleksibel sesuai kebutuhan anak dan adanya modifikasi atau penyesuaian untuk anak-anak yang mengalami hambatan intelektual. Adapun pelaksanaan pembinaan diutamakan untuk mengatasi kebutuhan khusus anak, baik masalah intelektual dan perilaku dilaksanakan dalam seting nonpanti dan panti untuk anak-anak yang tinggal di asrama sekolah.

Sampai penelitian ini berlangsung sekolah memiliki 23 orang guru. Lima belas orang guru sudah berstatus sebagai PNS, 8 orang guru lainnya masih menjadi guru honorer. Semua guru PNS sudah bersertifikasi guru dan 6 dari 8 guru honorer juga sudah bersertifikasi. Dari 15 guru PNS, hanya 3 orang guru yang berpangkat golongan III, sisanya (12 orang guru) sudah mencapai pangkat golongan IV A.

Jumlah siswa yang terdaftar di sekolah mencapai 80 orang siswa, namun yang aktif hanya sebagian saja. Kebanyakan siswa mengalami hambatan emosi dan perilaku serta hambatan kognitif.

\section{Subjek Penelitian}

Subjek penelitian ini adalah 19 orang guru SLB E Bina Putera yang masing-masing guru memiliki siswa dengan perilaku bermasalah yang sulit untuk ditangani. Subjek terdiri dari 12 orang guru perempuan dan 7 orang guru laki-laki. Usia subjek bervariasai dengan rentang 29 tahun sampai 60 tahun. Adapun latar belakang akademik subjek kebanyakan adalah sarjana pendidikan, satu orang subjek bergelar magister, dan satu orang subjek sarjana psikologi. Masa kerja subjek paling lama adalah 32 tahun (2 orang subjek). Data subjek penelitian divisualisasikan dalam Gambar 2.

\section{Permasalahan Perilaku Siswa}

Permasalah perilaku siswa ditemukan dari data FGD guru dan angket motivasi perila$\mathrm{ku}$ bermasalah yang diisi guru. Sebelum guru mengikuti FGD dan mengisi angket motivasi perilaku bermasalah, peneliti memberi pengantar materi mengenai konsep dan prosedur asesmen perilaku bermasalah. Setelah mendapatkan materi pengantar FGD, guru memilih siswanya yang mengalami perilaku bermasalah yang relatif sulit ditangani. Kemudian, guru memilih satu bentuk masalah perilaku yang sering muncul pada siswa tersebut. Satu perilaku bermasalah pada masing-masing siswa tersebut kemudian di analisa jenisnya. Setelah itu, guru dibantu oleh fasilitator mengisi angket motivasi perilaku adaptasi Motivation Assessment Scale Durran dan Crimmins. Pengisian angket tersebut bertujuan untuk mendapatkan pola perilaku bermasalah berupa motivasi atau latar belakang munculnya perilaku bermasalah yang paling sering dilakukan masing-masing siswa. Data yang diperoleh dari 19 orang siswa bermasalah perilaku di SLB E Bina Putera Solo menunjukkan jenis perilaku bermasalah pada siswa, dan motivasi atau latar belakang dari perilaku bermasalah. 

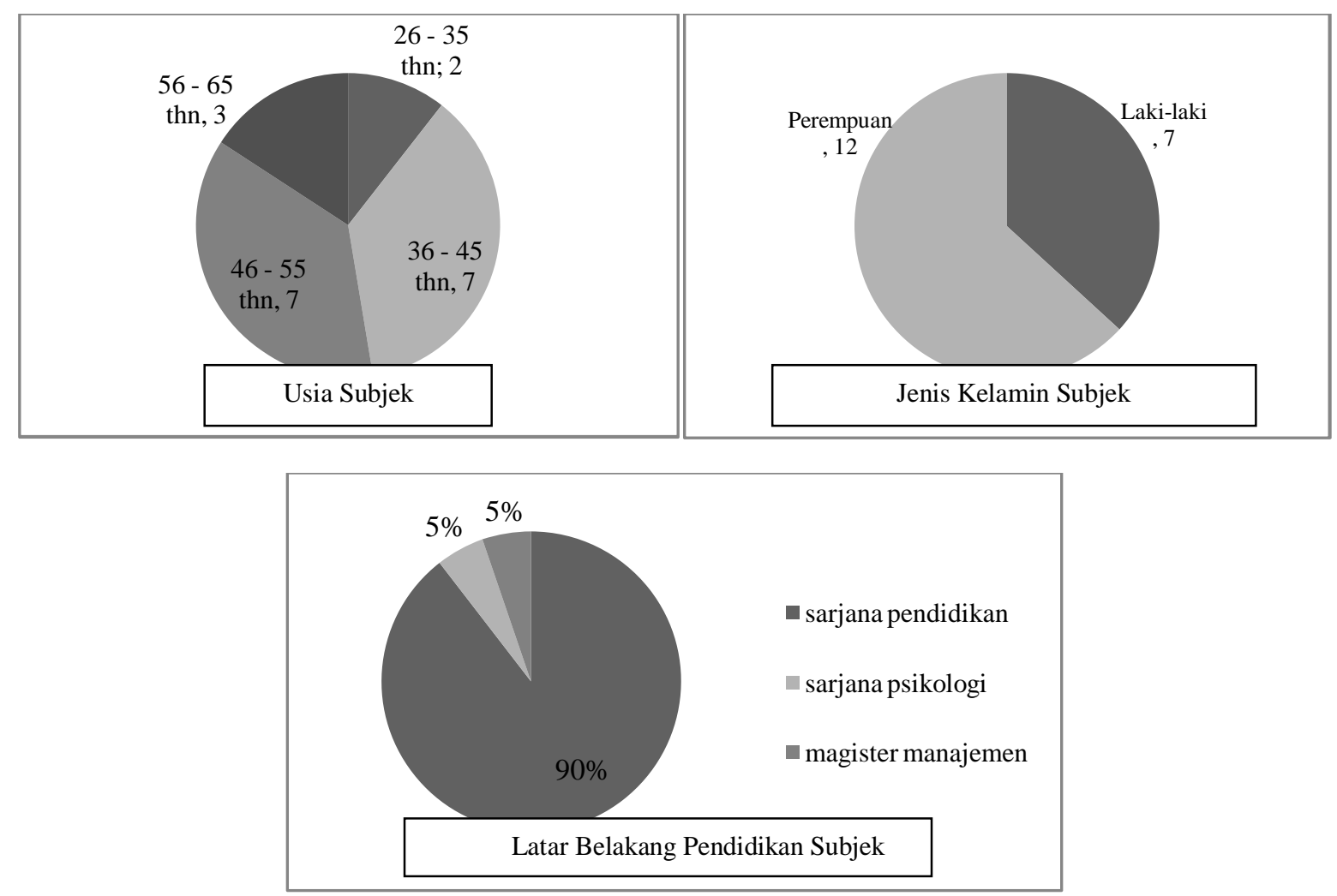

Gambar 2. Diagram Data Subjek Penelitian

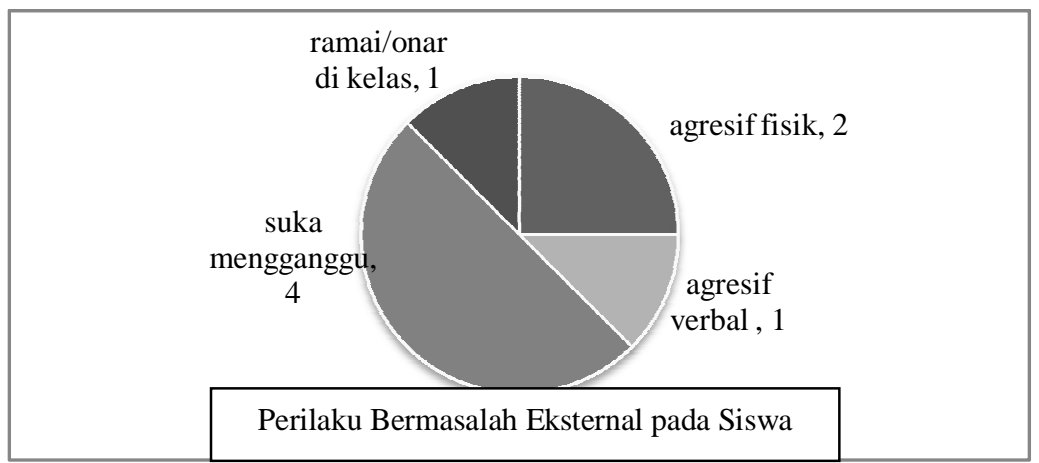

\section{Gambar 3. Diagram Munculnya Perilaku Bermasalah Eksternal pada Siswa}

Jenis perilaku bermasalah siswa menurut dampak digolongkan menjadi dua, yakni siswa bermasalah perilaku eksternal dan internal. Perilaku bermasalah eksternal merupakan perilaku yang dampak negatifnya dirasakan oleh orang lain. Perilaku tersebut berupa perilaku agresif fisik, agresif verbal, dan perilaku suka mengganggu teman. Dari 19 siswa, perilaku agresif fisik muncul pada 2 siswa, perilaku agresif verbal 1 siswa, 1 siswa sering berperilaku ramai dan onar di kelas, dan 4 siswa berperilaku suka mengganggu. Banyaknya siswa yang melaku- kan perilaku bermasalah eksternal dapat dilihat pada Gambar 3.

Gambar 3. menunjukkan perilaku bermasalah yang sering muncul pada kebanyakan siswa adalah suka mengganggu. Bentuk perilaku mengganggu berfariasi, di antaranya adalah usil kepada teman, dan mengganggu teman yang sedang belajar. Adapun Perilaku agresif yang dilakukan oleh dua orang siswa berupa memukul teman dan merusak benda.

Adapun perilaku bermasalah internal merupakan perilaku bermasalah yang dampaknya 
hanya dirasakan secara langsung oleh pelaku. Perilaku bermasalah internal yang muncul meliputi perilaku menghindar karena takut, 1 siswa, keluar kelas saat pembelajaran dilakukan oleh 2 siswa, tidak mau mengerjakan tugas 2 siswa, tidak menyelesaikan tugas 1 siswa, suka mencontek 1 siswa, dan beralih perhatian saat pembelajaran terjadi pada 1 siswa. Kemunculan gangguan perilaku internal pada siswa ditunjukkan pada Gambar 4.

Jenis perilaku juga dapat dianalisis dari sudut pandang kualitas perilaku. Menurut kualitas perilaku terdapat perilaku defisit dan perilaku ekses. Perilaku defisit merupakan perilaku yang bernilai kurang untuk konteks situasi siswa, misalnya perilaku tidak mau mengerjakan tugas. Sebaliknya, perilaku ekses merupakan perilaku yang berlebihan dilihat dari konteks situasi siswa, misalnya perilaku mudah beralih perhatian saat pembelajaran. Pada konsep pengelolaan perilaku, perilaku defisit harus ditingkatkan, sedangkan perilaku ekses harus dikurangi. Beberapa masalah perilaku eksternal dan internal pada siswa dapat digolongkan menjadi perilaku defisit dan perilaku ekses. Rinciannya perilaku yang termasuk pada perilaku defisit dan perilaku ekses terangkum dalam Tabel 1.

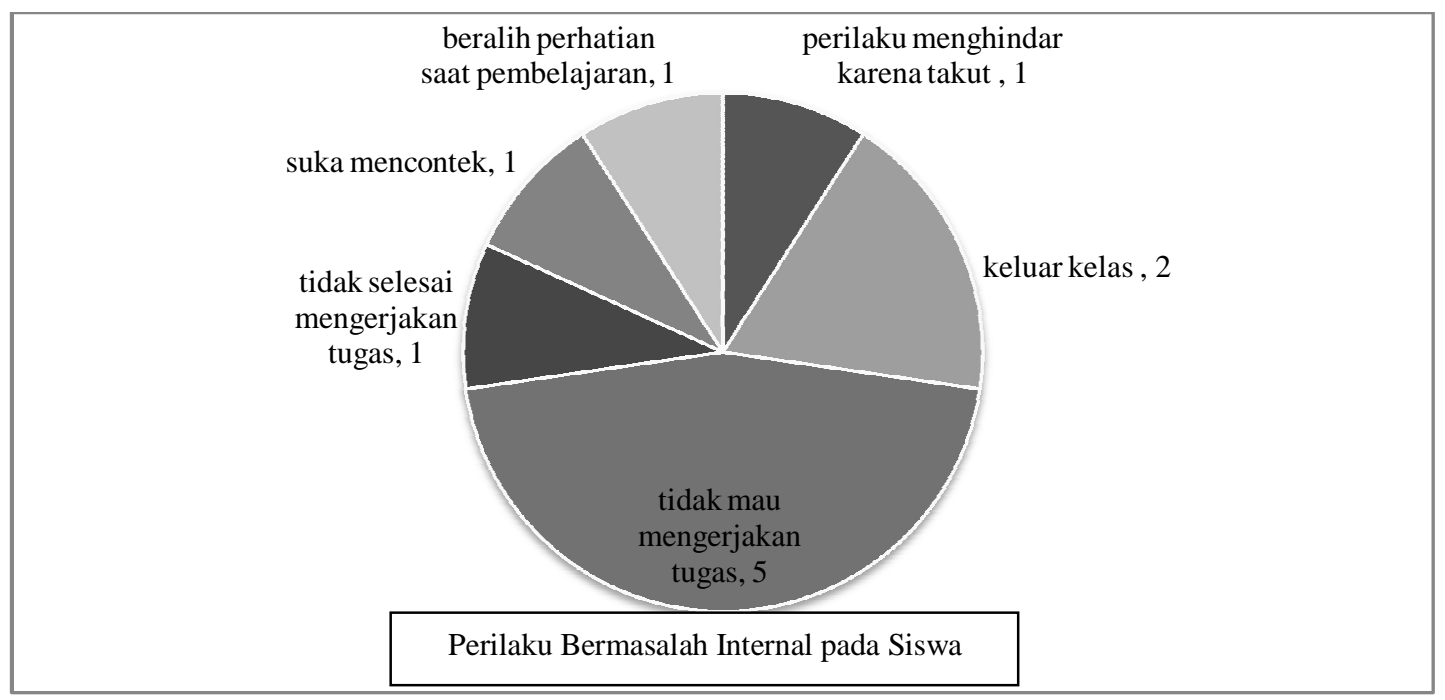

Gambar 4. Diagram Kemunculan Perilaku Bermasalah Internal pada Siswa

Tabel 1. Jenis Perilaku Bermasalah pada Siswa

\begin{tabular}{|c|c|c|c|c|}
\hline No. & Perilaku bermasalah & Jumlah & Defisit & Ekses \\
\hline & Eksternal & & & \\
\hline 1. & Agresif fisik & 2 & & $\mathrm{~V}$ \\
\hline 2. & Agresif verbal & 1 & & $\mathrm{~V}$ \\
\hline 3. & Mengganggu teman & 4 & & $\mathrm{~V}$ \\
\hline \multirow[t]{2}{*}{4.} & Ramai atau onar di kelas & 1 & & $\mathrm{~V}$ \\
\hline & Internal & & & \\
\hline 5. & Perilaku menghindar karena takut & 1 & V & \\
\hline 6. & Keluar kelas saat pembelajaran & 2 & & $\mathrm{~V}$ \\
\hline 7. & Tidak mau mengerjakan tugas & 5 & $\mathrm{~V}$ & \\
\hline 8. & Tidak menyelesaikan soal & 1 & V & \\
\hline 9. & Suka mencontek & 1 & $\mathrm{~V}$ & \\
\hline \multirow[t]{2}{*}{10.} & Tidak fokus pada pembelajaran & 1 & $\mathrm{~V}$ & \\
\hline & JUMLAH & $\begin{array}{l}19 \text { siswa dengan } \\
\text { perilaku } \\
\text { bermasalah }\end{array}$ & $\begin{array}{l}5 \text { jenis } \\
\text { perilaku } \\
\text { bermasalah }\end{array}$ & $\begin{array}{l}4 \text { jenis } \\
\text { perilaku } \\
\text { bermasalah }\end{array}$ \\
\hline
\end{tabular}


Tabel 2. Motivasi Perilaku Bermasalah Siswa

\begin{tabular}{|c|c|c|c|c|}
\hline No. & Sensory & Escape & Attention & Tangibel \\
\hline 1 . & $\begin{array}{l}\text { Beralih } \\
\text { perhatian }\end{array}$ & $\begin{array}{l}\text { Keluar masuk kelas saat } \\
\text { pembelajaran }\end{array}$ & & Suka mengganggu \\
\hline 2 & $\begin{array}{l}\text { suka } \\
\text { mengganggu }\end{array}$ & $\begin{array}{l}\text { Keluar masuk kelas saat } \\
\text { pembelajaran }\end{array}$ & $\begin{array}{l}\text { Ramai atau onar di } \\
\text { kelas }\end{array}$ & Suka mengganggu \\
\hline 3 . & & Suka memukul & & $\begin{array}{l}\text { Melempar } \\
\text { meja/kursi }\end{array}$ \\
\hline 4 . & & Tidak mau mengerjakan soal & & Agresif verbal \\
\hline 5 . & & Suka mengganggu & & $\begin{array}{l}\text { Tidak mau } \\
\text { mengerjakan tugas }\end{array}$ \\
\hline 6 . & & Tidak mau mengerjakan tugas & & \\
\hline 7 . & & Tidak mau mengerjakan tugas & & \\
\hline 8 . & & Suka mencontek & & \\
\hline 9 . & & Tidak selesai mengerjakan tugas & & \\
\hline 10. & & Tidak mau menulis & & \\
\hline 11. & & Menghindar karena takut & & \\
\hline & 2 Perilaku & 11 Perilaku & 1 Perilaku & 5 Perilaku \\
\hline
\end{tabular}

Perilaku bermasalah yang paling sering muncul pada 19 siswa tersebut kemudian dicari motivasi perilakunya dengan cara pengisian skala motivasi berperilaku adaptasi dari Motivation Assessment Scale Durrand \& Crimmins oleh guru. Skala motivasi berperilaku menunjukkan siswa bermasalah perilaku eksternal maupun internal dengan latar belakang sensori, menghindar (escape), memperoleh perhatian (attention), dan mendapatkan benda atau aktivitas yang disukai (tangible). Perilaku bermasalah siswa baik internal dan eksternal, maupun defisit dan ekses dilakukan oleh siswa dengan motivasi menghidari (escape). Data FGD menunjukkan bahwa perilaku bermasalah pada siswa tersebut memang dilakukan pada saat pembelajaran berlangsung. Biasanya perilaku muncul ketika guru menerangkan, memberi soal latihan atau tugas, dan pada kegiatan pembelajaran lainnya. Guru menyampaikan bahwa tingkat pengelolaan perilaku bermasalah tersebut sangat sulit dan seringkali terulang meskipun guru sudah memberi tindakan pada siswa. Sebaran motif perilaku bermasalah pada siswa dipaparkan pada Tabel 2.

\section{Kebutuhan Guru mengenai Penanganan Pe- rilaku Bermasalah Siswa}

Guru menyatakan tingkat pengaturan perilaku bermasalah pada siswa relatif sulit. Selama ini sekolah mengupayakan pengelolaan perilaku yang dilaksanakan oleh guru baik secara individual maupun bekerjasama dengan guru lain atau di bawah koordinasi kepala sekolah. FGD bersama guru menunjukkan fakta bahwa selama ini semua guru di sekolah yang memiliki siswa dengan perilaku bermasalah sudah mempraktikkan pengelolaan perilaku untuk mencegah dan menangani. Sifat pengelolaan perilaku yang dilaksanakan oleh guru atau sekolah untuk merespon perilaku bermasalah siswa selama ini adalah sebagai berikut.

- Dilaksanakan tanpa didasari asesmen perilaku yang prosedural dan mendalam. Asesmen perilaku penting agar diketahui jenis perilaku bermasalah, motivasi berperilaku, serta pola-pola perilaku lain seperti pemicu dan akibat yang muncul mengiringi perilaku. Asesmen yang tidak prosedural menyebabkan pemahaman guru mengenai perilaku bermasalah siswa tidak sistematis. Artinya, meskipun guru telah mengetahui jenis dan karakteristik perilaku bermasalah siswa secara lengkap karena lamanya interaksi guru dengan siswa tersebut, namun data yang 
dimiliki guru kurang tersistem. Data yang tidak tersistem sulit untuk menjadi pijakan untuk merumuskan pengelolaan perilaku yang sesuai.

- Menggunakan metode tradisional, yakni menerapkan penguat hadiah dan hukuman dengan tanpa kesepakatan dengan siswa di awal, insidental, dan kurang konsisten.

- Koordinasi antar guru maupun kepala sekolah dengan guru-guru untuk mengelola perilaku bermasalah sudah cukup baik. Hal ini ditandai dengan pernyataan semua guru bahwa semua guru di sekolah akan membantu 'mengawasi' dan memberi tindakan pada siswa yang sudah diketahui bersama sering bermasalah perilaku.

Kebutuhan guru dan sekolah akan program pengelolaan perilaku bermasalah dapat disimpulakan berdasarkan hasil asesmen perilaku yang menemukan pola-pola perilaku bermasalah siswa, fakta-fakta yang disampaikan guru mengenai pengelolaan perilaku bermasalah, serta pendapat kepala sekolah dan guru saat FGD. Kebutuhan tersebut seperti berikut.

- Pengetahuan dan keterampilan yang harus dimiliki guru mengenai bagaimana melaksanakan asesmen perilaku bermasalah yang terintegrasi dalam kegiatan pembelajaran.

- Pengetahuan dan keterampilan untuk merancang Program Pembelajaran Individual (PPI) yang sesuai dengan karakteristik individual siswa yang memasukkan unsur pengelolaan perilaku bermasalah dalam skenario pembelajaran.

- Pengetahuan dan keterampilan mengenai teknik-teknik modifikasi perilaku yang integratif dengan pembelajaran. Teknik modifikasi perilaku tersebut dapat diterapkan dalam pembelajaran sehari-hari.

\section{Pembahasan}

Berdasarkan temuan dalam asesmen perilaku yang dilakukan oleh guru-guru, maka ditemukan bahwa permasalahan perilaku yang dominan adalah perilaku menghindar (escape). Hal tersebut terjadi pada saat pembelajaran berlangsung. Untuk mengatasi hal tersebut, maka penelitian ini bermaksud membuat model pe- nanganan perilaku yang terintegrasi dengan pembelajaran. Beberapa tahapan dilakukan berdasar Killu (2008:142-146) antara lain: (1) asesmen situasi yang menjadi pemicu perilaku; (2) menetapkan validitas dari pemicu perilaku; (3) mendeskripsikan perilaku target dan strategi intervensi; (4) mengumpulkan data secara kolektif; (5) menerapkan rancangan penanganan perilaku secara akurat dan konsisten dari ke-5 tahap di atas poin 4 dan 5 belum dilakukan karena memerlukan implementasi di lapangan oleh karena itu hanya berfokus pada a, b dan c.

Berdasarkan analisis antecendent-behavior-consequence $(\mathrm{ABC})$ yang telah dilakukan oleh guru diperoleh situasi pemicu dari perilaku menghindar, yaitu pada saat pembelajaran berlangsung, saat diberi soal, pada waktu diminta mengerjakan tugas sehingga muncul perilaku menghindar, seperti: (1) keluar masuk kelas saat pembelajaran; (2) tidak mau mengerjakan soal; (3) suka mengganggu; (4) mencontek; dan (5) tidak selesai mengerjakan tugas. Carr \& LeBlanc (Geiger, dkk. 2008:22) menyatakan bahwa perilaku menghindar ditemukan paling banyak muncul pada anak dengan berkebutuhan khusus. Hal ini karena lingkungan pembelajaran dimungkinkan menjadi pemicu dari perilaku menghindar, contoh: tingkat kesulitan dari tugas yang diberikan, kecepatan dari pembelajaran yang disampaikan guru, dan strategi pemberian bantuan dapat menjadi pemicu perilaku menghindar dari anak.

Beberapa strategi disarankan oleh Geiger, dkk. (2010:23) untuk mengatasi adalah: memilih aktivitas yang sesuai minat anak, revisi kurikulum dan pembelajaran sesuai dengan kemampuan anak, penghilangan permintaan (demand fading), variasi penguat yang berbeda (differential reinforcement), extinction (menghilangkan perilaku bermasalah), pelatihan komunikasi fungsional siswa, dan segera mengatasi apabila perilaku menghindar muncul.

Strategi di atas mempunyai kelemahan dan kelebihan. Namun, Worcester \& McLaughlin (2013:621) menyatakan bahwa strategi yang paling efektif untuk mengurangi perilaku menghindar adalah extinction, negative reinforcement, pelatihan komunikasi fungsional, 
modifikasi dan akternatif pemberian tugas yang sesuai kemampuan anak.

Saran lain untuk memilih strategi mengatasi masalah adalah mengemas pembelajaran dengan menggunakan prinsip pendidikan humanistik. Prinsip ini menekankan pada penciptaan lingkungan pembelajaran siswa yang terbebas dari persaingan intens, disiplin kaku, dan rasa takut akan kegagalan (Subiyantoro, 2013:337).

Berdasarkan kesamaan dua pendapat dan saran tersebut, maka penelitian ini berfokus pada: pemilihan alternatif tugas, revisi pembelajaran, pelatihan komunikasi fungsional, dan extinction. Pemilihan strategi tersebut juga didasarkan pada kebutuhan guru-guru di SLB Bina Putra yang mencakup kebutuhan pengetahuan dan ketrampilan untuk melakukan: asesmen perilaku, pembuatan PPI dan menerapkan intervensi perilaku. Asesmen perilaku menjadi aktivitas yang dilakukan bersama guru-guru pada saat identifikasi dan asesmen masalah perilaku pada saat penelitian ini berlangsung. Pelatihan komunikasi, extinction dan pemberian alternatif tugas dapat dilakukan pada saat intervensi perilaku. Pembuatan PPI dapat dilakukan untuk penyesuaian kurikulum dan pembelajaran dengan kemampuan siswa.

Pemilihan aktivitas memberikan kesempatan pada anak untuk menentukan urutan atau waktu yang dipergunakan untuk menyelesaikan tugas (Dyer, Dunlap \& Winterling dalam Geiger dkk., 2010:23). Pemilihan aktivitas dimaksudkan agar anak saat menghindari suatu aktivitas tertentu dia dapat memilih aktivitas lain namun masih terkait dengan pembelajaran, contoh: memberikan 3-4 aktivitas pilihan (menyusun puzzle, melengkapi gambar, memilah gambar) dapat diberikan pada anak. Pada penerapan strategi ini, terdapat tiga hal yang perlu dipersiapkan (Geiger, dkk., 2010:23) adalah sebagai berikut.

- Memerlukan penyiapan rangkaian alternatif kegiatan dari pilihan aktivitas yang diberikan kepada anak.

- Memastikan aktivitas sesuai dengan kemampuan anak sebelum diberikan sebagai pilihan

- Strategi ini hanya efektif diberikan kepada anak yang mampu mengikuti pembelajaran.
Saat ini, di SLB tempat lokasi penelitian ini berlangsung belum menerapkan asesmen akademik secara mendalam sehingga tidak diketahui kemampuan akademik anak yang dapat memicu pemberian materi maupun tugas yang tidak sesuai (terlalu sulit atau terlalu mudah bagi anak) dengan kemampuan mereka dan hal tersebut memicu perilaku menghindar. Berdasarkan situasi tersebut penyesuaian kurikulum dan pembelajaran dipilih dalam penelitian ini untuk menghindari variabel pemicu munculnya perilaku menghindar dari faktor kurikulum dan pembelajaran, antara lain: (1) tugas yang terlalu sulit dan atau terlalu mudah (Dunlap, dkk. dalam Geiger, dkk., 2010:23); (2) lama durasi pemberian materi (Dunlap dalam Geiger dkk, 2010:23); (3) pemberian latihan yang terkumpul dalam satu waktu; (4) pemberian bantuan guru; (5) pengulangan materi yang berulang; dan (6) pemberian penguat yang jarang. Lalli, dkk. (dalam Geiger, dkk., 2010:24) menegaskan bahwa pemberian penguat (dapat berupa verbal maupun nonverbal) menjadi strategi yang lebih efektif untuk perilaku menghindar dibandingkan pemberian jeda pada saat pemberian tugas.

Perubahan kurikulum dan pengajaran tidak hanya berdampak pada pengurangan perilaku menghindar namun juga mampu mengarahkan pembelajaran menjadi efektif dan efisien karena didasarkan pada kemampuan awal anak (Geiger, dkk., 2010:24). Namun, untuk melakukan revisi kurikulum dan pengajaran diperlukan orang yang ahli untuk melakukan asesmen dan merubah strategi pembelajaran disamping membutuhkan waktu dan usaha yang lebih untuk melakukannya.

Extinction merupakan strategi yang dilakukan pada saat pembelajaran atau pemberian tugas. Pada saat anak menghindar maka guru tetap memberikan materi maupun memberikan penugasan sehingga ada kemungkinan terjadinya peningkatan perilaku menghindar di awal penerapan strategi ini. Oleh karena itu, diperlukan kombinasi dengan strategi lain.

Pelatihan komunikasi fungsional diberikan kepada anak agar ia dapat mengkomunikasikan keinginannya dengan tanda maupun lisan pada saat ia tidak nyaman saat pembelajaran 
dan atau mengerjakan tugas. Hal ini lebih berdampak pada perilaku sosial yang diterima dibandingkan langsung pergi atau tidak menyelesaikan tugas.

Alur penanganan perilaku menghindar dijabarkan dalam visualisasi (modifikasi model Geiger dkk (2010:9) yang ditunjukkan pada Gambar 5.

Model Modifikasi Perilaku Terintegrasi Pembelajaran untuk Anak dengan Masalah Perilaku di SLB E

Temuan penelitian mengenai pola-pola perilaku bermasalah pada siswa menunjukkan bahwa pada umumnya perilaku bermasalah dilakukan siswa dengan motivasi perilaku escape atau menghindari aktivitas dan tugas pembelajaran. Motivasi yang sering muncul setelah escape adalah tangibel. Beberapa perilaku bermasalah dilakukan siswa untuk mendapatkan benda atau kegiatan yang diinginkan. Misalnya anak memukul teman yang tidak mau memberikan benda yang disukai, atau anak tidak mau mengerjakan tugas karena ingin keluar kelas.

Temuan mengenai pola perilaku bermasalah siswa, pengelolaan perilaku bermasalah yang selama ini diterapkan sekolah, serta kebutuhan guru akan pengelolaan perilaku terintegrasi pembelajaran dapat digunakan untuk merancang model modifikasi perilaku terintegrasi pembelajaran untuk anak dengan masalah perilaku. Model tersebut dipaparkan dalam Gambar 6.

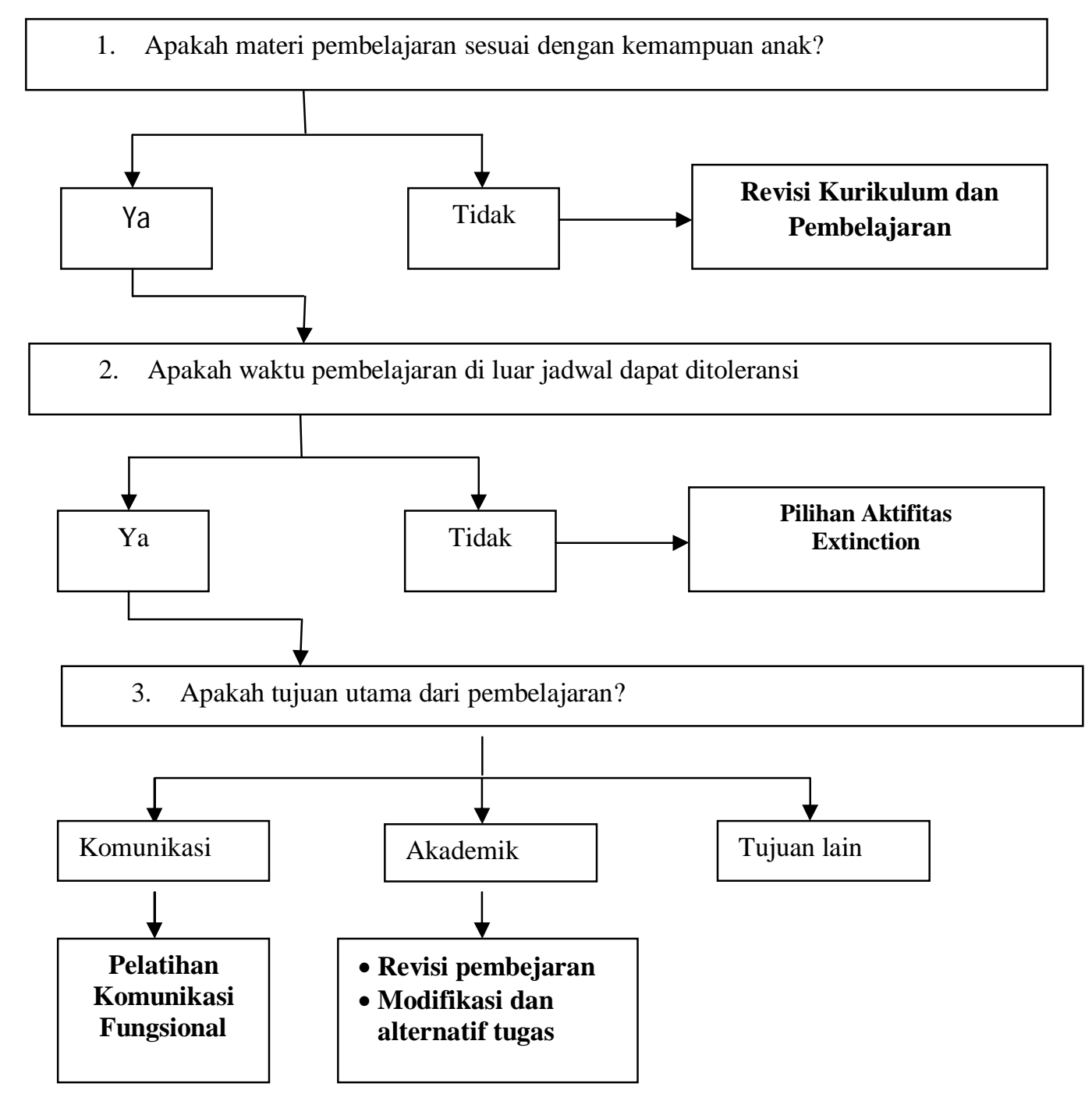

Gambar 5. Alur Penanganan Perilaku Menghindar 


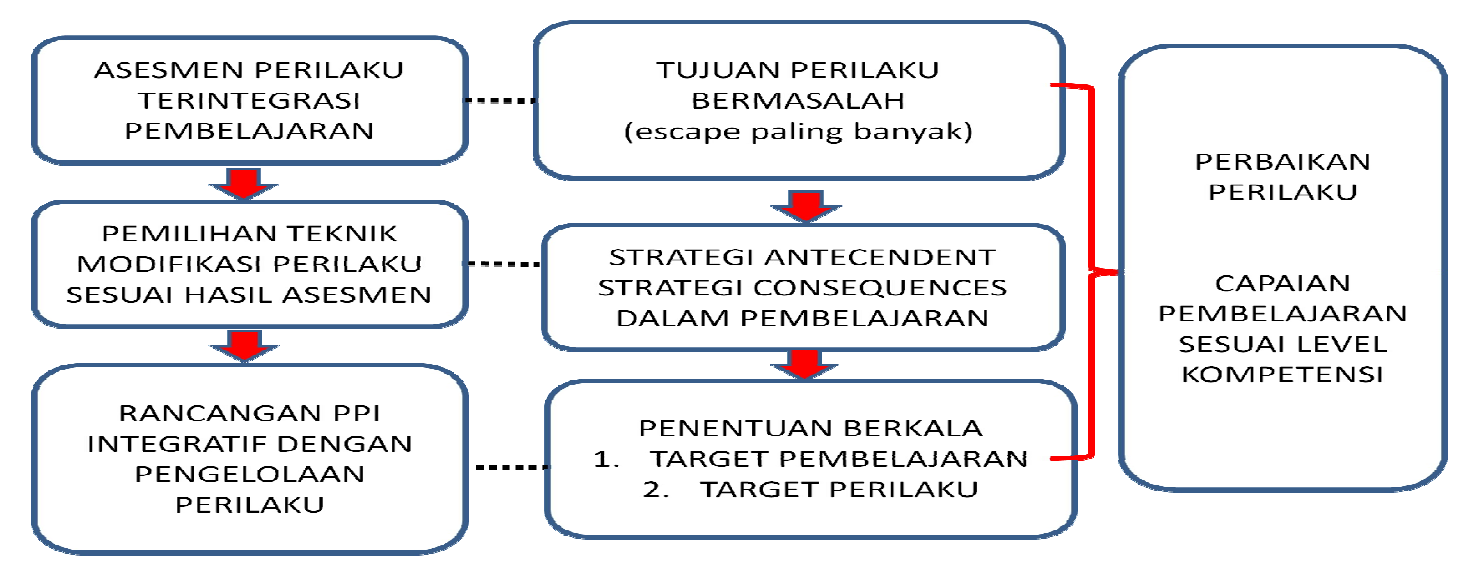

Gambar 6. Model Modifikasi Perilaku Terintegrasi Pembelajaran

\section{PENUTUP}

\section{Kesimpulan}

Berdasarkan hasil penelitian dan pembahasan kesimpulan penelitian ini dapat dikemukakan sebagai berikut.

- Permasalah perilaku siswa yang banyak ditemukan di SLB E Bina Putera Surakarta adalah perilaku tidak mau mengerjakan tugas pembelajaran (internal), dan mengganggu teman (eksternal) dengan berlatar belakang menghindar (escape).

- Kebutuhan guru dalam penanganan permasalahan perilaku di SLB E Bina Putera berupa pengetahuan dan keterampilan asesmen perilaku dalam pembelajaran, pengetahuan dan keterampilan merancang Program Pembelajaran Individual (PPI) yang sesuai dengan karakteristik individual siswa yang memasukkan unsur pengelolaan perilaku bermasalah dalam pembelajaran, menentukan teknik-teknik modifikasi perilaku yang integratif dengan pembelajaran.

- Model modifikasi terintegrasi pembelajaran dimulai dari temuan motif perilaku bermasalah yakni menghindar. Modifikasi perilaku diawali dengan asesmen mendalam mengenai ancedentent dan consequence dari perilaku, dan menerapkan perbaikan perilaku sesuai jenis dan motiv perilaku bermasalah. Rancangan intervensi meliputi komunikasi efektif siswa, revisi pembelajaran, dan extinction perilaku bermasalah. Intervensi dilakukan sebagai strategi antecendent dan strategi consequence. Hasil yang diharapkan adalah perbaikan perilaku dan peningkatan sikap dan capaian belajar.

\section{Saran}

Penelitian ini merekomendasikan saran untuk sekolah agar mempersiapkan program asesmen perilaku bermasalah terutama pada siswa yang bermasalah perilaku pada awal siswa bersekolah dan secara berkala untuk mengetahui perkembangan perilaku. Asesmen perila$\mathrm{ku}$ tersebut menjadi dasar pijakan intervensi pendidikan dan intervensi perilaku bermasalah pada siswa. Program asesmen tentu saja melibatkan peran guru, sehingga pengetahuan dan keterampilan guru mengenai praktik asesmen dan intervensi akademik dan perilaku perlu ditingkatkan. Sekolah dan guru hendaknya juga mempersiapkan instrumen asesmen dan intervensi agar pelaksanaannya dapat mencapai tujuan dengan baik.

\section{UCAPAN TERIMA KASIH}

Penelitian ini tidak akan berlangsung dan mendapatkan hasil yang optimal tanpa dukungan dan peran banyak pihak. Ucapan terima kasih disampaikan kepada Puslit Pendidikan Dasar Menengah dan Kejuruan Lembaga Penelitian dan Pengabdian Masyarakat UNY atas dukungan dana dan kesempatan meneliti. Kepada Fakultas Ilmu Pendidikan dan Jurusan Pendidikan Luar Biasa atas terimakasih atas kesempatan dan sarana prasarana yang membantu 
proses penelitian. Terimakasih juga disampaikan kepada para reviewer atas saran dan masukan untuk penelitian ini. Kepada Kepala Sekolah dan guru SLB Bina Putera Surakarta yang dilibatkan dalam pengambilan data, terima kasih atas kerjasama yang diberikan. Terakhir, ucapan terima kasih disampaikan kepada Redaktur dan segenap pengurus Jurnal Cakrawala Pendidikan yang telah memberikan mimbar bagi komunikasi ilmiah ini.

\section{DAFTAR PUSTAKA}

Alberto, P. A., \& Troutman, A. C. 1995. Applied Behavior Analysis for Teacher. New Jersey: Prentice-Hall Inc.

Arikunto, Suharsimi. 2005. Manajemen Penelitian. Jakarta: Rineka Cipta.

Muhammad Dwi PB. 2010. "Hubungan antara Depresi dengan Perilaku antisosial pada Remaja di Sekolah". UNDIP: Karya Ilmiah. Diakses pada [2 April 2013] di http://eprints.undip.ac.id/23644/1/Panji_ Baskoro.pdf

Gall, M.D., Gall, J.P., \& Borg, W.R. 2003. Educational Research, An Introduction. Seventh Edition. New York: Pearson Education, Inc.

Geiger, K. B., Carr, J. E., \& LeBlanc, L. A. 2012. "Function-Based Treatments for Escape-Maintained Problem Behavior: a Treatment-Selection Model for Practicing Behavior Analysts". Behavior Analysis in Practice , 3 (1), 22-32.

Joosten, A. V., \& Bundy, A. C. 2008. "The Motivation of Stereotypic and Repetitive Behavior: Examination of Construct Validity of the Motivation Assessment Scale". Journal Autism Developmental Disorder, 38, 1341-1348.

Killu, K. 2008. "Developing Effective Behavior Intervention Plans: Sugestions for School Personnel". Intervention in School and Clinic , 43 (3), 140-149.
Mahabbati, Aini. 2012. "Program Dukungan Perilaku Positif untuk Meningkatkan Keterampilan Sosial Anak dengan Gangguan Perilaku pada Seting Sekolah". Tesis. Magister Sains Psikologi Fakultas Psikologi UGM. Tidak diterbitkan.

Smith, J.D. 1998. Inclusion: School for All Students. USA: Wadsworth Publishing Co.

Smith, M. C. 2010. An Analysis of Interrater Agreement between the Motivation Assessment Scale (Mas), Questions about Behavioral Function. University of North Texas.

Subiyantoro. 2013. "Pengembangan Model Pendidikan Nilai Humanistik-Religius Berbasis Kultur Madrasah", dalam $\mathrm{Ca}$ krawala Pendidikan, November 2013, XXXII (3), hlm. 326-340.

Supported Inclusion, Early Childhood Service Team: Community Living Toronto. 2000. Summary Motivation Assessment Scale. Diunduh pada 9 Maret 2012, dari Supported Inclusion:http://www.thearcoftexas.org/site/DocServer/Dames_Challengi ng_Behaviors.pdf?docID=307

Wiguna, Tjin; Manengkie, PSK; Pamela. Christa; Rheza. AM; Hapsari. WA. 2010. "Masalah emosi dan Perilaku pada anak dengan remaja di Poliklinik Jiwa Anak dan Remaja RSUPN dr. Ciptomangunkusumo (RSCM) Jakarta". Sari Pediatri Vol 12 No 2 Desember 2010. Diakses pada [1 April 2013] di http://www.idai.or.id/saripediatri/pdfile/12-4-10.pdf

Worcester, L \& McLaughlin, T.F. 2013. "Comparing Effective Treaatments for Attention-Maintained and Escape-Maintained behaviors in Children with Behavior Disorders: Brief Review and Analysis". International Journal of Basic Applied Science Vol. 01, No. 03, Jan 2013, pp. 621-627. 